\title{
AKUNTABILITAS PENGELOLAAN ALOKASI DANA DESA DI KECAMATAN AMPEL KABUPATEN BOYOLALI
}

\author{
Oleh: \\ Dian Fawzy Ilmiah' ${ }^{1)}$, Anita Wijayanti' ${ }^{2}$, Purnama Siddi ${ }^{3)}$ \\ Universitas Islam Batik Surakarta \\ ilmiahdian@gmail.com
}

\begin{abstract}
Abstrak
Tujuan penelitian ini adalah untuk mengetahui akuntabilitas perencanaan, pelaksanaan dan penatausahaan, dan pelaporan dan pertanggungjawaban Alokasi Dana Desa di Kecamatan Ampel Kabupaten Boyolali tahun 2018. Teknik pengambilan sampel pada penelitian ini adalah random sampling dengan menggunakan sampel sebanyak 3 desa di Kecamatan Ampel Kabupaten Boyolali. Sedangkan untuk teknik analisis data yang digunakan dalam penelitian ini yaitu menggunakan teknik analisis tematik. Berdasarkan hasil pengujian analisis tematik, akuntabilitas perencanaan alokasi dana desa dilakukan secara transparan dan partisipatif. Akuntabilitas pelaksanaaan dan penatausahaan berjalan dengan transparan, patisipatif, akuntabel, tertib dan disiplin anggaran. Sedangkan untuk akuntabilitas pelaporan dan pertanggungjawaban berjalan dengan transparan, akuntabel, tertib dan disiplin anggaran.
\end{abstract}

\section{Kata kunci : Akuntabilitas, Dana Desa}

\section{PENDAHULUAN}

Desa merupakan masyarakat hukum yang memiliki batas wilayah sehingga masyarakat memiliki wewenang untuk mengatur dan mengurus urusan pemerintahan, kepentingan masyarakat setempat, hak asal usul maupun hak tradisional yang diakui serta dihormati dalam sistem pemerintahan Negara Kesatuan Republik Indonesia (UU Nomor 6 Tahun 2014 tentang Desa). Desa memiliki kewenangan yaitu dalam bidang penyelenggaraan pemerintahan desa, pelaksanaan pembangunan desa, pembinaan kemasyarakatan desa, dan pemberdayaan masyarakat desa berdasarkana asal-usul, adat istiadat, serta ide dan tanggungjawab dari masyarakat (Kholmi,2016). Dalam undang-Undang Nomor 6 Tahun 2014 tentang Desa telah mengatur bahwa keuangan dan aset desa yang digunakan untuk memberikan pelayan publik khususnya masyarakat adalah dana yang berasal dari Pendapatan Asli Daerah. Baik Pemerintah dari pusat hingga Kabupaten atau Kota mempunyai kewajiban untuk memberikan transfer dana, hibah ataupun donasi bagi 
Desa. Salah satu dana yang ditransfer oleh pemerintah untuk mendukung pembangunan di Desa adalah dengan memberikan Alokasi Dana Desa (ADD) (Putra et al, 2107). Alokasi Dana Desa (ADD). Alokasi Dana Desa (ADD) merupakan dana perimbangan dari Pemerintah Pusat dan Pemerintah Daerah untuk Kabupaten / Kota dimana dana tersebut dibagi secara merata / seimbang antara desa satu dengan desa yang lainnya, demikian maka disebut dengan Alokasi Dana Desa kemudian disingkat ADD (Peraturan Pemerintah Nomor 72 Tahun 2005). Alokasi Dana Desa (ADD) sebagai bantuan dana stimulan atau perangsang untuk mendorong dalam membiayai program penyelenggaraan pemerintahan desa, pelaksanaan pembangunan, pembinanaan kemasyarakatan, dan pemberdayaan masyarakat (Permendesa Nomor 5 tahun 2015). Untuk mengelola Alokasi Dana Desa (ADD) maka dibutuhkan beberapa tahap-tahap pengelolaan, meliputi perencanaan, pelaksanaan dan penatausahaan, serta pelaporan dan pertanggungjawaban.

Pembagian Alokasi Dana Desa ditentukan oleh beberapa hal, sehingga jumlah Alokasi Dana Desa per desa berbeda-beda. Beberapa hal tersebut adalah luas wilayah, jumlah penduduk, status desa, dan tingkat kemiskinan. Setiap desa memperoleh Alokasi Dana Desa digunakan untuk mecapai tujuan. Tujuan adanya Alokasi Dana Desa ada untuk : 1). Pemenuhan pemberian penghasilan tetap dan tunjangan perangkat desa dan kepala desa; 2). Pemenuhan jaminan kesehatan dan jaminan ketenagakerjaan; 3). Pemenuhan BPD (operasional BPD dan insentif BPD); 4). Pemenuhan operasional baik RT/RW dan kegiatan kantor rutin; 4). Pemenuhan di bidang pemberdayaan perempuan atau PKK. Rumusan masalah dari penelitian ini antara lain :

1. Bagaimana akuntabilitas perencanaan Alokasi Dana Desa (ADD) di Kecamatan Ampel Kabupaten Boyolali?.

2. Bagaimana akuntabilitas pelaksanaan dan penatausahaan Alokasi Dana Desa (ADD) di Kecamatan Ampel Kabupaten Boyolali?.

3. Bagaimana akuntabilitas pelaporan dan pertanggungjawaban Alokasi Dana Desa (ADD) di Kecamatan Ampel Kabupaten Boyolali? 


\section{LANDASAN TEORITIS}

Menurut UU No. 6 Tahun 2014 Dana Desa merupakan dana yang bersumber dari anggaran pendapatan dan belanja negara yang diperuntukkan bagi desa yang ditransfer melalui anggaran pendapatan dan belanja daerah kabupaten/kota dan digunakan untuk membiayai penyelenggaraan pemerintahan, pelaksanaan, pembangunan, pembinaan kemasyarakatan, dan pemberdayaan masyarakat.

Pedoman Alokasi Dana Desa (ADD) yang tertuang dalam Peraturan Pemerintah Nomor 47 Tahun 2015, Alokasi Dana Desa (ADD) merupakan dana perimbangan yang diterima kabupaten/kota dalam Anggaran Pendapatan dan Belanja Daerah kabupaten/kota setelah dikurangi Dana Alokasi Khusus. Alokasi Dana Desa (ADD) diberikan kepada desa berdasarkan perhitungan Alokasi Dana Desa Merata dan Alokasi Dana Desa Proporsional.

Akuntabilitas adalah suatu kewajiban untuk memberikan pertanggungjawaban dan menerangkan kinerja seseorang maupun pimpinan suatu unit organisasi kepada pihak yang berwenang dan memiliki hak untuk meminta pertanggungjawaban.

\section{a. Perencanaan}

Perencanaan adalah kegiatan atau proses dimana sejumlah orang menyalurkan pemikiran serta kesepakatan secara matang untuk mengelola keuangan desa dalam rangka pembangunan maupun pemberdayaan masyarakat (Rahum, 2015). Pengelolaan perencanaan Alokasi Dana Desa agar mencapai akuntabilitas maka dilaksanakan dengan prinsip transparan dan partisipatif.

b. Pelaksanaan dan Penatausahaan

Pelaksanaan pembangunan desa harus sesuai dengan yang telah direncanakan oleh masyarakat bersama dengan aparat pemerintahan. Masyarakat dan aparat pemerintahan juga berhak mengetahui dan melakukan pengawasan terhadap jalannya pemembangunan desa. Pengelolaan pelaksanaan dan penatausahaan Alokasi Dana Desa agar mencapai akuntabilitas maka dilaksanakan dengan prinsip transparan, partisipatif, skuntabel, tertib dan didiplin anggaran.

c. Pelaporan dan Pertanggungjawaban 
Pelaporan merupakan suatu proses dimana hasil kegiatan yang telah dicapai dalam penatausahaan dikelola dan disampaikan kepada msyarakat, BPD dan pengawas (Rahum, 2015). Pengelolaan pelaporan dan pertanggungjawaban Alokasi Dana Desa agar mencapai akuntabilitas maka dilaksanakan dengan prinsip transparan, akuntabel, tertib dan disiplin anggaran

Penelitian oleh Abu Rahum (2015) hasil penelitian ini menunjukkan bahwa laporan petanggungjawaban Alokasi Dana Desa (ADD) dalam pembangunan fisik sudah berjalan dengan baik. Hal ini dapat dilihat dari seluruh kegiatan pengelolaan Alokasi Dana Desa (ADD) yang sudah berjalan serta dapat dilaporkan dan dipertanggungjawabkan oleh pemerintah desa kepada masyarakat.

Penelitian oleh Siti et al (2017) hasil penelitian ini menunjukkan bahwa Akuntabilitas dalam perencanaan Alokasi Dana Desa (ADD) dalam pengelolaannya sudah berjalan dengan baik dan sudah sesuai dengan peraturan perundang-undangan yang berlaku. Perencanaan Alokasi Dana Desa (ADD) dilakukan dengan kegiatan musyawarah perencanaan dan pembagunan pada tingkat dusun, desa, maupun kecamatan yang melibatkan masyarakat, BPD, serta LPMD.

Penelitian oleh Syahadatina (2017) hasil penelitian ini menunjukkan bahwa Akuntabilitas Pelaksanaan Alokasi Dana Desa (ADD) mencerminkan prinsip transparan. Prinsip transparan ini juga didukung oleh prinsip partisipasi masyarakat dalam proses pelaksanaan. Lalu untuk prinsip akuntabilitas telah berjalan dengan sepenuhnya dengan pertanggungjawaban secara fisik dan administrasi yang sudah selesai dan lengkap.

Penelitian oleh Nasehatun dan Anisa (2017) hasil penelitian ini menunjukkan bahwa Akuntabilitas Penatausahaan Alokasi Dana Desa (ADD) telah berjalan sesuai dengan peraturan perundang-undangan yang berlaku. Namun ada beberapa hal yang belum pernah terjadi yaitu terkait dengan prosedur pengisian kas desa, dalam penelitian ini menerangkan bahwa bendahara desa tidak pernah menyimpan uang desa. Dari pernyataan ini bisa dikatakan bahwa Kepala Desa adalah pihak utama yang mengatur pengelolaan Alokasi Dana Desa (ADD). Akan tetapi secara keseluruhan bahwa dalam penatausahaan pengelolaan keuangan desa sudah mencapai tingkat akuntabilitas. 
Penelitian oleh Putra et al (2017) hasil penelitian ini menunjukkan bahwa Akuntabilitas Pelaporan Alokasi Dana Desa (ADD) telah berjalan dengan baik, namun ada beberapa prosedur yang belum tepat waktu dalam pelaksanaannya. Penelitian ini juga menyatakan bahwa ada dua pelaporan yang dilaporkan secara berkala oleh bendahara yang intinya akan dipertanggungjawabkan setiap bulannya kepada Kepala Desa serta laporan akhir yang akan disampaikan kepada Bupati paling lambat 31 Desember tahun yang berekenaan.

\section{Kerangka Pemikiran}

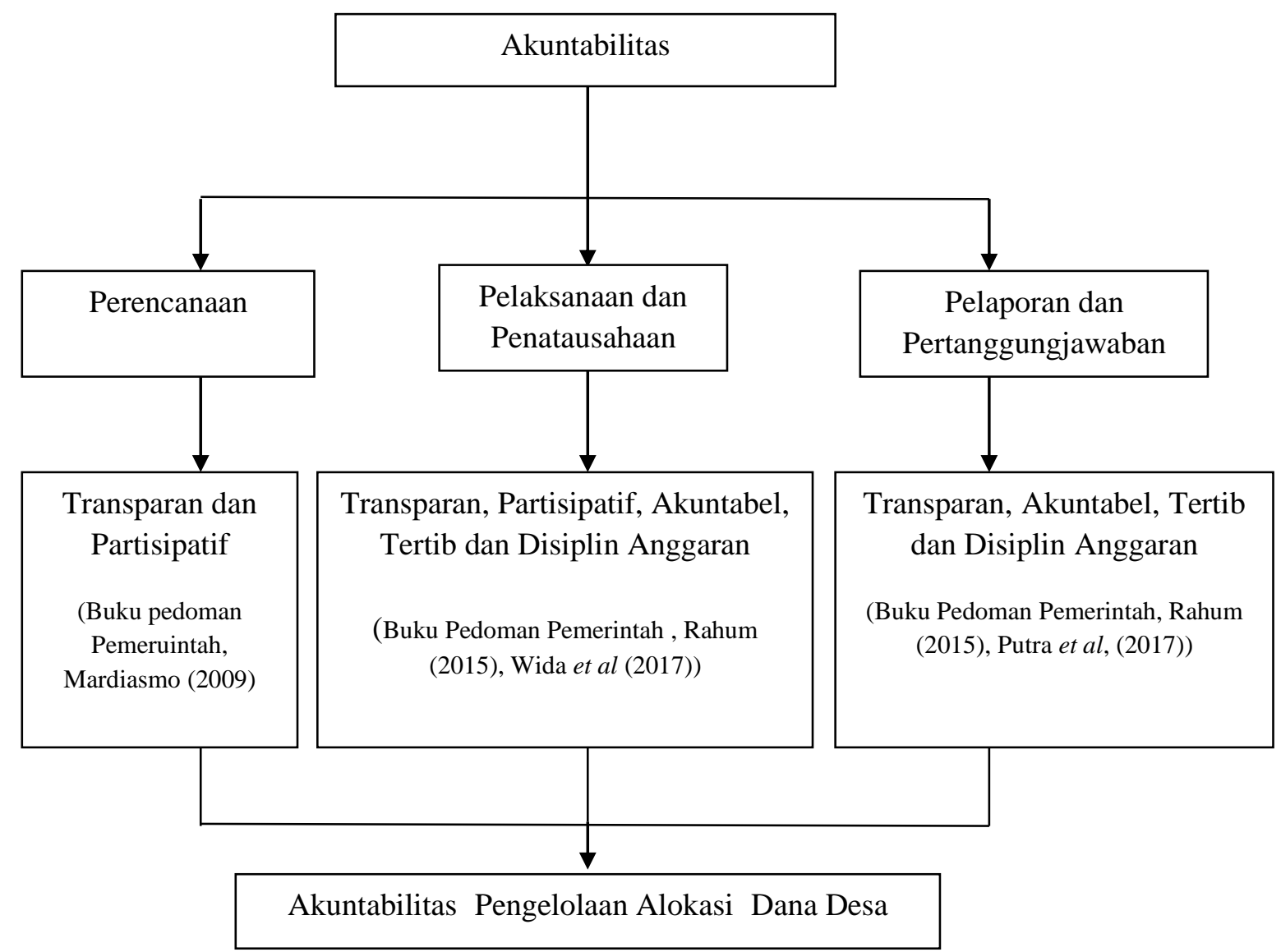

\section{METODE PENELITIAN}

Jenis penelitian ini adalah penelitian deskriptif. Penelitian deskriptif ini didasarkan pada tujuan yang ingin dicapai yaitu memperoleh data atau gambaran yang jelas mengenai Alokasi Dana Desa (ADD). Penelitian ini bersifat kualitastif. Penelitian kualitatif merupakan penelitian yang dilakukan sebagai metode untuk meneliti suatu keadaan secara langsung atau alamiah dimana peneliti adalah kunci utama (Sugiyono, 2007). 
Variabel penelitian pada pengelolaan Alokasi Dana Desa terdiri dari: (1).perencanaan Alokasi Dana Desa dengan indikator berupa rtransparan dan pertisipatif. (2). Pelaksanaan dan penatausahaan Alokasi Dana Desa dengan indikator transparan, pertisipatif, akuntabel, tertib dan disiplin anggaran. (3). Pelaporan dan pertanggungjawaban Alokasi Dana Desa dengan indikator transparan, akuntabel, tertib dan disiplin anggaran.

Lokasi penelitian yang dipilih oleh peneliti adalah 3 desa di Kecamatan Ampel kabupaten Boyolali yaitu Desa Tnaduk, Desa Selodoko dan Desa Sidomulyo. Data yang digunakan dalam penelitian ini adalah data primer. Data yang diberikan langsung kepada pengumpul data (Sugiyono, 2015). Pada penelitian ini data primer didapat dari kegiatan wawancara dan observasi. Wawancara merupakan proses pengumpulan data yang dilakukan dengan cara bertemu langsung antara penanya (interviewer) dengan narasumber (interviewee) (Masiyah, 2016). Obyek yang akan diteliti disini adalah Alokasi Dana Desa (ADD). Lalu subyek yang akan dimintai keterangan mengenai obyek yang akan diteliti adalah seseorang yang terlibat langsung dengan pengelolaan Alokasi Dana Desa (ADD) dari perencanaan, pelaksanaan dan penatausahaan, hingga pelaporan dan pertanggungjawaban. Setelah melakukan pengamatan langsung, peneliti juga menyimpan hasil observasi dalam bentuk dokumentasi foto sebagai bukti bahwa keadaan tertulis sesuai dengan kenyataan yang dapat dilihat secara langsung.

Sumber data sekunder adalah data yang diberikan secara tidak langsung kepada pengumpul data (Sugiyono, 2015). Pada penelitian ini data sekunder diperoleh melalui laporan keuangan Alokasi Dana Desa (ADD) pada tahun 2018. Dengan menggunakan laporan keuangan maka akan dapat diketahui bahwa pengelolaan sudah mencapai pada kata Akuntabilitas.

Dalam penelitian ini data responden yang digunakan adalah pemerintah desa di Kecamatan Ampel Kabupaten Boyolali yang menerima Alokasi Dana Desa (ADD) pada tahun 2018. Responden yang akan diwanwancarai meliputi :
a) Kepala Desa
b) Bendahara Desa
c) Staf lain yang terlibat dalam pengelolaan Alokasi Dana Desa (ADD)
d) Staf Kecamatan yang menerima dan menyalurkan Alokasi Dana Desa (ADD) 
Metode analisis data yang digunakan dalam penelitian ini adalah deskriptif kualitatif dengan menggunakan teknik analisis data yang disebut teknik analisis tematik. Analisis data tematik adalah analisis yang dilakukan setelah mengumpulkan data melalui wawancara dan observasi. Analisis data tematik bertujuan untuk memahami lebih dalam mengenai akuntabilitas pengelolaan Alokasi Dana Desa dengan mengelompokkan berdasarkan tema-tema agar lebih mudah untuk dipahami.

\section{HASIL DAN PEMBAHASAN}

\section{Akuntabilitas perencanaan Alokasi Dana Desa}

Perencanaan Alokasi Dana Desa merupakan tahap awal yang dilaksanakan desa. Penrencanaan Alokasi Dana Desa (ADD) memiliki beberapa indikator agar bisa berhasil. Indikator tersebut adalah transparan dan partisipatif.

\section{a. Transparan}

Diharapkan dengan sikap transparan ini masyarakat bisa mengetahui bagaimana struktur perencanaan yang akan dilakukan pemerintah desa. Pada studi kasus yang sudah dilakukan oleh peneliti di Desa Tanduk, Selodoko dan Sidomulyo, ternyata dari masing-masing desa memberikan jawaban yang hampir sama perihal sikap transparan. Hal ini sesuai dengan pernyataan yang dikemukakan oleh bapak Agung Nugroho selaku sekretaris Desa Tanduk berikut ini.

"Kan perencanaan itu diawali dari musyawarah Dusun biasanya di tingkat $R W$ dimana perencanaan itu dimulai dari bawah (dari tingkat $R W$ ). Lalu dalam Musdus itu dimusyawarahakan apa saja kegiatan yang diusulkan dari dusun ke desa, nanti dibawa ke Musdus (Musyawarah Desa). Nah di Musdus nanti Desa memutuskan kira-kira kegiatan yang mendesak itu yang mana dan yang diprioritaskan nanti kita anggarkan di APBDes".

Setiap desa menerapkan sikap transparan dengan cara memberitahukan secara langsung berapa nominal Alokasi Dana Desa yang diperoleh oleh desa itu sendiri. Ada pula cara penyampaian transparansi dana dengan memberi tahukan kepada BPD, lalu BPD menyampaikan ke masyarakat.

\section{b. Partisipatif}


Pada perencanaan Alokasi Dana Desa selain memperhatikan aspek transparan juga memperhatikan aspek partisipatif. Partisispasi masyarakat bisa disampaikan misalnya melalui Musrenbangdes dimana masyarakat dan pemerintah desa berkumpul untuk bersama-sama menentukan perencanaan apa yang akan dilakukan untuk pekembangan desa tersebut. Pada perencanaan juga membutuhkan yang namanya pertisipasi. Studi kasus yang sudah dilakukan oleh peneliti memberikan hasil bahwa pada Desa Tanduk dan Selodoko sangat terbuka sekali terhadap hak masyarakat untuk berpendapat. Hal ini sesuai dengan peryataan yang diberikan oleh bapak Agung Nugroho selaku sekretaris Desa Selodoko berikut ini :

“Jadi pada saat perencanaan itu partisipasi dari masyarakat sediri, jadi masyarakat yang butuh. Misal dukuh saya ingin mengaspal jalan, pak saya mau ngaspal jalan dengan panjang sekian, lebar sekian, ketebalan sekian dan mereka membuat RAB sendiri"

Dua desa ini mengadakan musyawarah dusun (Musdus) yang dilakukan di masing-masing dukuh. Setelah malaksanakan Musdus dan memperoleh beberapa kesepakatan, maka pihak Pemerintah desa akan melanjutkan usulan dusun itu dalam musyawarah Desa(Musdes) yang mana dalam Musdes nantinya akan dipilih manakah kegiatan yang akan atau segera untuk dilaksanakan.

\section{Akuntabilitas pelaksanaan dan penatausahaan Alokasi Dana Desa}

Pelaksanaan dan penatausahaan adalah proses dimana suatu perencanaan dilakukan dan pada saat melaksanakan perlu adanya suatu pencatatan atau pengelolaan dana oleh bendahara desa. Agar pelaksanaan dan penatausahaan berjalan dengan baik, maka perlu adanya indikator yang berupa transparan, partisipatif, tertib dan disiplin anggaran.

\section{a. Transparan}

Pada pelaksanaan perlu adanya sikap transparan dari Pemerintah Desa untuk selalu menginformasikan kepada masyarakat tentang berapa jumlah dana yang digunakan. Berikut adalah studi kasus yang peneliti lakukan untuk mengetahui bagaimana pemerintah desa menerapkan sikap transparan saat proses pelaksanaan. Hal ini sesuai dnegan pernyataan bapak Yon Aprilianto selaku kaur keuangan Desa Selodoko berikut ini : 
"Jadi begini dek, setiap selesai dalam kegiatan kami selalu menginformasikan perihal capaian kegiatan dan juga kami menyampaikan realisasi anggaran yang telah digunakan dalam kegiatan tersebut, jadi semua masyarakat dapat megetahui bagaimana dana itu digunakan dek”

Berdasarkan studi kasus yang dilakukan pada tiga desa tersebut, dapat ditarik kesimpulan bahwa Pemerintah Desa sudah menerapkan sikap transparan kepada masyarakat terkait berapa dana yang dikeluarkan untuk melakukan proses pelaksanaan.

\section{b. Pertisipatif}

Pelaksanaan Alokasi Dana Desa perlu adanya partisipasi agar pelaksanaan bisa berjalan dengan lancar dan cepat terselesaikan. Bentuk sikap partisipatif dapat dilihat melalui studi kasus yang dilakukan oleh peneliti pada 3 desa tersebut. Seperti pernyataan yang diberikan oleh bapak Yon Aprilianti selaku Kaur Keuangan Desa Selodoko berikut ini :

"Partisispasinya begini, ada sistem gotong royong. Gotong royong itu dalam tanda kutip. Kalau kita ambil dari APBDes itu intruksi dari pemerintah kan padat karya (dibayar), harga standar Selodoko bukan standar manapun tapi standar Selodoko sendiri. Jadi bayarnya tukang yang wajarnya Selodoko ya itu yang dibayar. Jadi pelaksanaan khusus di pembangunan kami full bayaran”

Partisipasi msyarakat itu berbeda-beda. Ada yang perpar

tisi penuh dengan cara gotong toyong, ada yang berpartisipasi sebagai pegawai padat karya dalam pelaksanaan, dan ada juga yang tidak dilibatkan partisipasinya dalam melakukan pelaksanaan karena sudah sangat berpedoman dengan peraturan yang diberikan oleh Pemerintah Daerah atau Kabupaten.

\section{c. Akuntabel}

Pada proses penatausahaan sangat diperhatikan perihal bagaimana akuntabelnya suatu pencatatan. Akuntabel adalah bagaimana pemerintah desa mencatat semua kegiatan pengeluaran dan memasukan dana sesuai dengan bukti yang sebenarnya. hal ini dapat dilihat dari pernyataan bapak Agung Nugroho selaku sekretaris Desa Tanduk berikut ini:

"Karena penatausahaan kan sekarang lewat sistem Siskeudes itu. jadi di sistem antar penerimaan kita, pengeluaran kita dengan rekening yang ada di 
bank itu harus sama. Jadi seumpama penatausahaan sudah selesai tapi saldo di laporan dengan kenyataan itu berbeda maka tidak bisa. Jadi antara penatausahaan dengan pembukuan harus sama. Kalau ada selisih berarti dalam penatausahaan masih belum tepat"

Dari studi kasus yang telah dilakukan maka dapat ditarik kesimpulan bahwa penerapan sikap akuntabel pada penatausahaan Alokasi Dana Desa sudah berjalan akuntabel. Hal ini didukung dengan adanya sistem atau aplikasi yang diberikan oleh Pemerintah Daerah yang dinamakan dengan Siskeudes (Sistem Keuangan Desa). Adanya sistem ini maka Pemerintah Desa diharapkan dapat membuat penatausahaan dengan jujur dan sesuai dengan bukti yang sebenarnya.

\section{d. Tertib dan disiplin anggaran}

Pada pelaksanaan dan penatausahaan perlu adanya tertib dan disiplin anggaran. Dimana dana yang digunakan susuai dengan rencana penganggaran yang sudah dibuat ketika perencanaan awal atau sesuai dengan RAB dan pelaksanaan yang sudah berjalan. Hal ini sesuai dengan pernyataan yang diberikan oleh ibu Sugiyanti selaku sekretaris Desa Sidomulyo berikut ini:

"Iya sudah pasti tertib mbak, soalnya diklopkan dengan aplikasi Siskeudes mbak. Jadi ya tidak ada yang menyimpang. Kegaiatan-kegiatan sesuai dengan nominalnnya sesuai dengan RABnya, sesuai dengan Draf APBDesa kita. Jadi untuk ADD ini kita clear (bersih) sesuai dengan Juknis yang sudah diberikan"

Maka dapat ditarik kesimpulan bahwa tertib dan disiplin anggaran pada penatausahaan ini sudah berjalan dengan tertib dan disiplin. Hal ini juga didukung dengan adanya sistem yang sudah menyediakan format pencatatan sehingga mempermudah Pemerintah Desa dalam menyusun penatausahaan. Apabila ada kendala, Pemerintah Desa sudah bisa mengatasi kendala tersebut tanpa membuat anggaran menjadi kurang atau boros.

\section{Akuntabilitas pelaporan dan pertanggungjawaban Alokasi Dana Desa \\ Pelaporan merupakan hasil kegiatan yang telah dicapai dalam penatausahaan dikelola dan disampaikan kepada masyarakat, BPD dan pengawas (Rahum, 2015). Tidak hanya pelaporan, melainkan pemerintah juga harus mempertanggungjawabkan laporan yang telah dibuat tersebut. Suatu lapotan dan pertanggugjawban dikatakan}


akuntabel apabila sudah memenuhi indikator transparan, akuntabel serta tertib dan disiplin anggaran.

\section{a. Transparan}

Pada pelaporan dan pertanggungjawaban perlu adanya sikap transparan. Pemerintah Desa harus transparan kepada pihak-pihak yang berhak meminta pelaporan dan pertanggungjawaban. Berdasarkan studi kasus yang telah dilakukan, dapat dilihat bahwa Desa Tanduk, Selodoko dan Sidomulyo sudah menerapkan sikap transparan dengan melaporkan dan mempertanggungjawabkan laporannya kepada pihak yang tingkatannya lebih tinggi yaitu pihak kecamatan dan Pemeritah Daerah. Selain pihak kecamatan dan kabupaten, ketiga desa tersebut juga transparan kepada masyarakat. Hal ini dapat dilihat dari pernyataan bapak Agung Nugroho sebagai sekretaris Desa Tanduk berikut ini :

“yang jelas kita kan membuat laporan realisasi anggaran untuk disetiap akhir tahun kegiatan dimana laporan realisasi itu dibuat dengan kita membuat LPPD yang bentuknya berupa MMT besar, sehingga setiap warga itu tahu alokasi anggaran yang ada di desa sekian dengan realisasi belanja desa sekian itu kita buatkan MMT besar. Sehingga warga bisa mengatahui kinerja pemerintahan desa itu sepeti apa selain itu kita juga buat laporan kepada dinas yang bersagkutan yaitu Dispermasdes kabupaten Boyolali, kita harus memberikan laporan realisasi itu setiap tahun. itu bukan hanya ADD namun semua anggaran yang diterima oleh desa itu semua dilaporkan. Baik dana dari pemerintah kabupaten, pemerintah propinsi maupun dari pusat kita harus buat laporan"

Sehingga masyarakat tidak bertanya-tanya bagaimana Pemerintah Desa mengelola Alokasi Dana Desa tersebut.

\section{b. Akuntabel}

Saat pelaporan dan pertanggungjawaban juga memperhatikan perihal sikap akuntabel, dimana Pemerintah Daerah dalam melaporkan dan mempertanggungjawabankan harus dengan sikap akuntabel. Sikap akuntabel yang dimaksud disini adalah Pemerintah Desa membuat laporan dan pertanggungjawaban dengan format dan keadaan keuangan yang sesungguhnya. Setelah peneliti melakukan studi kasus pada tiga desa kaitannya dengan 
penerapan sikap akuntabel pada pelaporan dan pertanggungjawaban. Hal ini dapat dilihat dari pernyataan ibu Sugiayanti selaku sekretaris Desa Sidomulyo berikut ini :

"Itu ada rekomendasi Camat yaitu kegiatan yang mau dicairkan apa saja. Kemudian bukti-bukti penerimaan kegiatan itu. kwitansi, ya itu mbak. Paling kegiatan rutin ADD itu kan itu mbak. Kalau bukti untuk mancairkan ADD itu ada mbak pertanggungjawabannya ada mbak. Jadi komplit. Kerjasama kita kan sudah kita tunjuk dengan pihak ketiga"

Maka peneliti dapat menarik kesimpulan tentang penerapan sikap akuntabel pada pelaporan dan pertanggungjawaban Alokasi Dana Desa bahwa pelaporan dan pertanggungjawaban sudah dilakukan secara akuntabel, bersdasarkan atas bukti-bukti yang sesungguhnya terjadi tanpa dibuat-buat.

\section{c. Tertib dan Disiplin Anggaran}

Selain transparan dan akuntabel, dalam pelaporan dan pertanggungjawaban juga harus memperhatikan tertib dan disiplin anggaran dimana semua pelaporan dan pertanggungjawaban yang diberikan sesuai dengan peraturan atau ketentuan yang berlaku serta disiplin pada anggaran yang sudah sistimasikan sebelumnya. Pada Desa Tanduk mendapat mendapat Alokasi Dana Desa sebesar Rp 465.853.000. desa Selodoko mendapat Alokasi Dana Desa sebesar Rp 403.324.000. desa Sidomulyo mendapat Alokasi Dana Desa sebesar Rp 483.696.000. ketiga desa tersebut sudah menggunakan Alokasi Dana Desa sesuai dengan dana yang diberikan. Kesimpulan yang dapat diambil dari studi kasus yang sudah dilakukan tentang tertib dan disiplin anggaran tersebut adalah, bahwa Pemerintah Desa Tanduk, Seodoko dan Sidomulyo sudah menggunakan dana dengan tertib dan disiplin serta dikelola dengan semaksimal mungkin.

\section{PEMBAHASAN}

\section{Akuntabilitas Perencanaan Alokasi Dana Desa di Kecamatan Ampel Kabupaten Boyolali}

Perencanaan Alokasi Dana Desa (ADD) dilakukan dengan kegiatan musyawarah perencanaan dan pembagunan pada tingkat dusun, desa, maupun kecamatan yang melibatkan masyarakat, BPD, serta LPMD (Siti et al ,2017). Perencanaan dilakukan dengan prinsip transparan dan partisipatif. Prinsip transparan dilakukan dengan 
menyampaikan langsung kepada masyarakat melaui pemasangan banner yang didalam banner tersebut sudah tertera berapa ADD yang didapat oleh desa tersebut. Cara lain yang digunakan pemerintah desa untuk menyampaikan informasi tentang ADD ini adalah dengan menyampaikan terlebih dahulu kepada BPD dusun setempat dan kemudian BPD menyampaikan langsung kepada masyarakat melalui musyawarah dusun (Musdus). Prinsip partisipatif pada perencanaan dilakukan dengan mengadakan Musdus dan Musdes agara masyarakat turut berperan untuk menyumbangkan ide dan aspirasinya untuk mengembangkan desa mereka.

\section{Akuntabilitas Pelaksanaan dan Penatausahaan Alokasi Dana Desa di Kecamatan Ampel Kabupaten Boyolali}

Penelitian oleh Syahadatina (2017) hasil penelitian ini menunjukkan bahwa Akuntabilitas Pelaksanaan Alokasi Dana Desa (ADD) mencerminkan prinsip transparan. Prinsip transparan ini juga didukung oleh prinsip partisipasi masyarakat dalam proses pelaksanaan. Lalu untuk prinsip akuntabilitas telah berjalan dengan sepenuhnya dengan pertanggungjawaban secara fisik dan administrasi yang sudah selesai dan lengkap . Pelaksanaan Alokasi Dana Desa menggunakan prinsip transparan, partisipatif, akuntabel, tertib dan disiplin anggaran. Prinsip transparan sudah dilakukan dengan cara Pemerintah Desa menyampaikan semua dana yang sudah dianggarkan kepada masyarakat. Prinsip partisipatif ditunjukkan melalui gotong royong atau pemberdayaan masyarakat (mengadakan lowongan pekerjaan bagi masyarakat setempat yang belum memiliki pekerjaan/ padat karya). Prinsip akuntabel pelaksanaannya didukung dengan adanya aplikasi Siskeudes yangmana dalam penggunaan Siskeudes sangat membantu Pemerintah Desa dalam menjaga keakuntabelannya serta tertib dan disiplin dalam menggunakan anggran Alokasi Dana Desa.

\section{Akuntabilitas Pelaporan dan Pertanggungjawaban Alokasi Dana Desa di \\ Kecamatan Ampel Kabupaten Boyolali}

Penelitian oleh Putra et al (2017) hasil penelitian ini menunjukkan bahwa Akuntabilitas Pelaporan Alokasi Dana Desa (ADD) telah berjalan dengan baik, namun ada beberapa prosedur yang belum tepat waktu dalam pelaksanaannya. Pelaporan dan pertanggungjawaban Alokasi Dana Desa di Kecamatan Ampel sudah menerapkan prinsip transparan, akuntabel, tertib dan disiplin anggaran. 
Penerapan prinsip transparan ditunjukkan dengan penyampaian laporan baik kepada pihak kecamatan, kabupaten, maupun pusat/propinsi. Prinsip akuntabel yang diterapkan ditunjukkan dengan penggunaan Siskeudes. Penggunaan Siskeudes ini dalam memasukkan data harus sesuai dengan bukti-bukti yang ada. Hasil pengolahan dari aplikasi Siskeudes ini nantinya akan menghasilkan laporan Realisasi Alokasi Dana Desa. Dimana dalam laporan Realisasi tersebut dapat ditunjukkan bahwa Pemerintah Desa sudah mengelola Alokasi Dana Desa semaksimal mungkin. Pemaksimalan penggunaan dan pengelolaan Alokasi Dana Desa ini menjadi penilaian bahwa Pemerintah sudah menggunakan dana dengan Tertib dan disiplin.

\section{KESIMPULAN}

Setelah dilakukan peneitian pada beberapa desa di Kecamatan Ampel Kabupaten Boyolali yaitu Desa Tanduk, Desa Seodoko dan Desa Sidomulyo maka peneliti menemukan hasil tentang Akuntabilitas Pengeolaan Alokasi Dana Desa. Akuntabilitas Pengelolaan Alokasi Dana Desa di Kecamatan Ampel Kabupaten Boyolali pada tahun 2018 dapat diambil kesimpulan sebagai berikut

Tahap perencanaan Alokasi Dana Desa pada tiga desa diKecamatan Ampel sudah menerapkan sikap transparan dan partisipatif. Hal ini dapat dilihat pada saat pemerintah desa dengan keterbukaannya menginformasikan berapa jumlah dana yang didapat dan mempersilahkan masyarakat sendiri untuk menyusun perencanaan kegiatan yang akan dilakukan. Bentuk keterbukaan (transparan) pemerintah desa dilakukan lewat musyawarah dusun atau disampaikan ke BPD lalu BPD menginfomasikan ke masyarakat. Lalu agar terbentuk suatu partisipasi masyarakat pemerintah desa mengadakan musyawarah dusun (Musdus) dan musyawarah desa (Musdes) supaya masyarakat bisa menyalurkan gagasan dan ide untuk kemajuan dan perkembangan desa itu sendiri.

Tahap pelaksanaan dan penatausahaan Alokasi Dana Desa pada tiga desa di Kecamatan Ampel Kabupaten Boyolali telah menerapkan prinsip atau sikap transparan, partisipatif, akuntabel serta tertib dan displin anggaran. Prinsip transparan dapat diihat dari pemerintah desa menyerahkan berapa biaya yang dibutuhkan untuk ditentukan sendiri oleh masyarakat. Prinsip partisipatif disini terdapat beberapa cara yang diterapkan oleh pemerintah desa. Partisipatif bisa diwujudkan dengan sistem gotong royong, bayaran, dan ada juga yang hanya 
melibatkan anggotan kantor desa saja untuk mengelola dana tersebut karena dirasa memang hanya untuk kepentingan pihak intern kantor desa saja. Akuntabel dalam penetausahaan sudah sangat akuntabel karena sudah menggunakan sistem atau aplikasi yang dinamakan Sisten Keuangan Desa (Siskeudes) yang disediakan dari pemerintah daerah dan sudah pasti keakuntabelannya. Selanjutnya pada tertib dan disiplin anggaran disini pemerintah desa juga mengandalkan penggunaan Siskeudes tersebut, dimana setiap data dana yang dimasukkan dalam sistem harus sesuai dengan kenyataan atau bukti yang ada.

Tahap pelaporan dan pertanggungjawaban Alokasi Dana Desa pada tiga desa diKecamatan Ampel Kabupaten Boyolai sudah dilaksanakan dengan transparan, akuntabel serta tertib dan disiplin anggaran. Transparan dalam pelaporan dan pertanggungjawaban sudah dilakukan dengan transparan. Hal ini dapat dilihat dari pemerintah desa menyampaikan hasil realisasi kepada masyarakat dalam bentuk laporan lembaran atau kertas dan laporan dalam bentuk MMT besar yang dipasang didepan kator desa atau tempat-tempat yang mudah diakses oleh masyarakat. Akuntabel yang dilakukan pemerintah desa dalam pelaporan dan pertanggungjawaban disini dapat dilihat dari pemrintah desa menggunakan sistem atau aplikasi Siskeudes untuk melaporkan hasil pengelolaan kepada pemerintah daerah, propinsi maupun pusat. Tertib dan disipin anggaran yang dilakukan oleh pemerintah desa dapat diihat dari laporan besaran dana yang sudah terealisasi dengan dana yang diberikan oleh pemerintah daerah. Pemerintah desa sudah menerapkan dengan seimbang antara dana yang masuk dengan dan yang keluar (terealisasi) sehingga pemerintah desa dalam pelaksanaannya tidak terjadi kekurangan dana.

\section{Saran}

Berdasarkan keterbatasan penelitian yang sudah duraikan diatas maka peneliti dapat memberikan saran yaitu:

1. Peneiti selanjutnya sebaiknya mencari contact person dari informan yang akan dituju, sehingga antar peneliti dengan informan dapat menentukan waktu yang tepat dan baik untuk melakukan wawancara.

2. Sebaiknya penelliti selanjutnya menginformasikan dahulu apa saja data yang akan di dokumentasikan dan menanyakan apakah ada data dalam bentuk soft file 
sehingga sebelum berlangsung wawancara informan bisa menyiapkan dokumen terlebih dahulu.

3. Sebaiknya peneliti selanjutnya lebih memperhitungkan waktu pelaksanaan dan pengerjaan peneitian. Lebih memanage lagi pembangian pengerjaan usulan penelitian, pelaksanaan penelitian dengan pengolahan data sehingga tidak kekurangan waktu.

\section{DAFTAR PUSTAKA}

Badan Pengawasan Keuangan dan Pembangunan, 2015, Petunjuk Pelaksanaan Bimbingan dan Konsultasi Pengelolaan Keuangan Desa, Jakarta.

Direktorat Jenderal Perimbangan Keuangan, 2017, Buku Pintar Dana Desa, Jakarta Pusat.

Direktorat Jenderal Perimbangan Keuangan, 2017, Buku Saku Dana Desa, Jakarta.

Hanafie, H., Nugraha, A., Huda,M. (2019). Akuntabilitas Dana Desa (Kajian Tentang Akuntabilitas Dana Desa Di Kecamatan Masalembu, Kabupaten Sumenep). Jurnal Ilmu Pemerintahan, 4(1), 1-8.

Hidayah, N., Wijayanti, I. (2017). Akuntabilitas Pengelolaan Dana Desa (DD) Studi Kasus Pada Desa Wonodadi Kecamatan Ngrayun Kabupaten Ponorogo. Jurnal Akuntansi dan Sistem Informasi, 2(1), 1-7.

Kholmi, M. (2016). Akuntabilitas Pengelolaan Alokasi Dana Desa: Studi di Desa Kedungbetik Kecamatan Kesamben Kabupaten Jombang. Jurnal EkonomikaBisnis, 07(02), 143-152.

Kustono, AS., Purnamasari, P., Supatmoko, D. (2017). Akuntabilitas Pengelolaan Alokasi Dana Desa di Desa Ledokombo Kecamatan Ledokombo Kabupaten Jember Tahun 2015. Jurnal Ekonomi Bisnis dan Akuntansi, IV(2), 141-147.

Nafidah, LN., Anisa, N. (2017). Akuntabilitas Pengelolaan Keuangan Desa di Kabupaten Jombang. Jurnal Ilmu Akuntansi, 10(2), 273-288.

Peraturan Menteri Desa, Pembangunan Daerah Tertinggal., dan Transmigrasi Nomor 5 Tahun 2015 Tentang Pembangunan Kawasan Pedesaan

Peraturan Pemerintah Nomor 47 Tahun 2015 Tentang Peraturan Pelaksanaan UndangUndang Nomor 6 Tahun 2014 Tentang Desa

Peraturan Pemerintah Republik Indonesia Nomor 72 Tahun 2005 Tentang Desa

Prastowo Andi, 2014, Metode Penelitian Kualitatif dalam Perspektif Ramcangan Penelitian, AZ-RUZZ MEDIA, Jogjakarta. 
Putra, PAS., Sinarwati, K., Wahyuni, MA. (2017). Akuntabilitas dan Transparansi Pengelolaan Alokasi Dana Desa (ADD) di Desa Bubunan Kecamatan Seririt Kabupaten Buleleng. Jurnal Pendidikan Akuntansi, 8(2).

Rahum, A. (2015). Pengelolaan Alokasi Dana Desa (Add) Dalam Pembangunan Fisik Desa Krayan Makmur Kecamatan Long Ikis Kabupaten Paser. Jurnal Ilmu Pemerintahan, 3(4), 1623-1636.

Riyanto, T. (2015). Akuntabilitas Finansial Dalam Pengelolaan Alokasi Dana Desa (Add) Di Kantor Desa Perangat Selatan Kecamatan Marangkayu Kabupaten Kutai Kartanegara. Jurnal Administrasi Negara, 3(1), 119-130.

Sugiyono, 2015, Metode Penelitian Kuantitatif, Kualitatif, dan R\&D, ALFABETA, Bandung.

Syahadatina, R. (2017). Akuntabilitas Pengelolaan Alokasi Dana Desa di Desa Rapa Laok Kecamatan Omben Kabupaten Sampang. Jurnal Akuntansi dan Investasi, 2(1), 1-18.

Undang-Undang Nomor 6 Tahun 2014 Tentang Desa

Wida, SA., Supatmoko, D., Kurrohman, T. (2017). Akuntabilitas Pengelolaan Alokasi Dana Desa (ADD) di Desa- Desa Kecamatan Rogojampi Kabupaten Banyuwangi. Jurnal Ekonomi Bisnis dan Akuntansi, IV (2), 148-152.

Arifiyanto, Dwi Febri, dan Kurrohman, Taufik. 2014. Akuntabilitas Pengelolaan Alokasi Dana Desa di Kabupaten Jember. Jurnal Riset Akuntansi dan Keuangan. Jember, Vol.2, No.3, p.473-485, Universitas Pendidikan Indonesia

Pradana, I Made dan Ayu Komang, Anantawikrama, 2014. Membedah Akuntabilitas Praktik Pengelolaan Keuangan Desa Pakraman Kubutambahan, Kecamatan Kubutambahan, Kabupaten Buleleng, Provinsi Bali (Studi Interpretif pada Organisasi Publik Non Pemerintah)

Gray, R. Owen,D.C. Owens, D. Evans, R. Zadek,S. 1997. Struggling With the Praxis of Social Accounting; Stakeholders, Accountability, Audit, and Procedures, Accounting, Auditing, and Accountability Journal, Vol. 10, N0. 3, pp.325-364

Mardismo. 2009. Akuntansi Sektor Publik. Penerbit Andi, Yogyakarta. 